\title{
Management Strategies for Curbing the Prevalence of Plagiarism in Project Writing amongst Students of Imo State University Oweeri
}

\author{
Florence Chizoba Emenalo
}

Faculty of Education, Imo State University, Nigeria

Copyright $\bigcirc 2016$ by authors, all rights reserved. Authors agree that this article remains permanently open access under the terms of the Creative Commons Attribution License 4.0 International License

\begin{abstract}
Many undergraduate students copy a lot from other people's research project reports and many graduate students lack the capacity to carry out and report the research work required of them for graduation. This research ascertained the views of Science and Arts Education students on the causes of the problem, types, and the strategies the university adopts to solve the problem since it has been noted by scholars that science students are prone to plagiarism. This is done through a case study of Faculty of Education, Imo State University, Owerri, Nigeria. A clustered proportionate random sample size of 200 drawn from the 500 Science and Arts based final year students of the Faculty was used for the study. Four and three research questions and hypotheses respectively were formulated. A 36 item researcher made four point rating scale of Strongly Agree (SA) Agree (A) Disagree (D) and Strongly Disagree (SD) was the instrument for data collection. Frequency tables, Mean scores with 2.50 decision point and t-test are the statistical tools used for the analysis of the data. The study revealed inadequate time, improper teaching of Research method, ignorance, absence of a university policy etc. as the causes of student project plagiarism, submission of project written by someone else, revising previously written project etc. are the commonly engaged types of plagiarism by students. It also found that University uses the teaching of research method, rules and regulations etc. to curb plagiarism while rejection of plagiarized project, publication of culprits names, workshops etc. are the preventive measures. Based on these, recommendations were made that plagiarism test should be run for finished projects, project workshop be mounted for students, proper and adequate teaching of Research method and project Supervision should be done by the lecturers.
\end{abstract}

Keywords Plagiarism, Management, Strategies, Curbing, Prevalence and Project Writing

\section{Introduction}

A University is a citadel of learning where scholars of different fields of specialization operate and function to create, build and refine knowledge, impact knowledge, ideas and skills on students and also help them realize their hidden potentials. Universities are therefore charged with the responsibilities of engaging in teaching, research and community service with the aim of producing high- level manpower as provided in section 6of the Nigerian National Policy on Education (NPE), Federal Republic of Nigeria $\left(\right.$ FRN 2004) ${ }^{[1]}$. The policy further reiterated that research and development are among the ways through which goals of Tertiary education can be achieved.

Further stressing this point, Nwokeocha $(2014)^{[2]}$, opined that an education system without an institutionalized culture of research is like an empty rolling drum, full of noise but of no effect. Moreover, change brought about by education will be slow and hardly positive if research does not take its proper place, hence a research should be the concern of each one genuinely interested in scholary and educational development.

It is universally accepted that research is a veritable instrument for providing solutions to existing problems and for knowledge creation and innovations (Nwankwoala and Nwaneri, 2000) ${ }^{[3]}$. Similarly, Educational Research as opined by Nwana $(1985)^{[4]}$, gives room for new knowledge and innovations that lead to the improvement in education. This explains why lecturers often embark on education research and also teach their students how to carryout research work, hence research writing and reports become a prerequisite for the award of any degree to any student by the universities. This point is further emphasized by Nwana $(2008)^{[5]}$ that

Universities are statutorily required to undertake research and that by all levels of the academic population namely, students and teachers alike. Undergraduate courses include as much as 4 units 
credit for research project which could be written up in the form of thesis. Students are taught Research Methodology that enables them to understand all the processes of conducting research works in their various fields of study pp178-179.

However, originality, proper articulation and organization of thoughts and ideas as well as logical and conclusive presentation of ideas or information, which are marks of scholarship, are required of any good research work. A scholar is expected to create original work and cite the sources used to support argument. The acknowledgement of such, respects and appreciates the contributions of other authors which also adds values to the researchers work. Failure to cite and acknowledge authors and sources to ones work amounts to plagiarism. Moreover, it has been noted by U.S Public Health Services $(1989)^{[6]}$, that plagiarism is the most widely recognized unethical lapses in scientific writing, and that both the intentional and unintentional types of plagiarism occur with some frequencies in the sciences. Similarly, Newstead, Franklyn-Strokes and Armead $(1999)^{[7]}$, have identified science and technology students as being prone to plagiarism due to their ability to manipulate data. This therefore makes it imperative to compare the views of Science and Arts Education students of the university on the issue under study.

\section{Plagiarism}

Bal $(2007)^{[8]}$ defines plagiarism as a practice of using other's ideas and texts, and claiming them as one's own. It is a Latin word, "Plagiarius" meaning kidnapping or plunder. It is a very serious offence in the academic world, and is seen as academic theft. Bal, $(2007)^{[8]}$ further stated that plagiarism, is sometimes a moral and ethical offence rather than a legal one because some instances of plagiarism are, not within the scope of copy right infringement, a legal offence. That notwithstanding, there are some cases where the act of plagiarism has caused some academics their jobs, demotions or even litigations.

\section{Types of Plagiarism}

Gibaldi as citied in Bal, $(2007)^{[8]}$, stated that Plagiarism could be unintentional or deliberate, it could be of ideas, languages or data, but regardless of the nature, plagiarism is plagiarism. Different types of plagiarism exists, these include:

a) obtaining and submitting as one's own, paper written by someone else.

b) doing copy and paste of texts without acknowledging the original authorship.

c) paraphrasing the original ideas of others without referencing them

d) attributing the citation of a text to a false authorship

e) changing the number of respondents and responses in a research data

f) re-using a writers previously published material without acknowledgement.

\section{Why Students Plagiarize}

Scholars such as Bhatlora and Nathan, cited inBal, $(2007){ }^{[8]}$ have advanced these as reasons why students plagiarize (1) Language and content problems, (2) Laziness, (3) Absence of adequate and Stringent laws of Copyright, (4) Ignorance of the Implications of plagiarism, (5) Ignorance of the roles citation of sources play within the structure of academic argument etc. In the same vein, Nwana (1985 and $2008)^{[4][5]}$,presented time constraints, and expensiveness of research work as reasons for students plagiarism. He explained that when a final year student sees that he has a limited time to complete the research works, he ends up doing a haphazard work, or duplicate an already existing completed published works with minor changes. Similarly, Awujo (2013) $)^{[9]}$ adduced inadequate teaching of research methods and improper project supervision by some lecturers to be reasons for students anxiety and copying in project writing.

\section{Tips for the Avoidance of Plagiarism}

There, is no doubt that the world wide web (www.) has become the popular source of accessing information for students papers but that does not justify any reason for students plagiarism in project, writing.

In view of this, there is the need to acquaint students, on ways of avoiding plagiarism. These tips/ways as noted by Indiana University (2004) ${ }^{[10]}$ include.

a) Using quotations in everything that comes directly from a text.

b) Paraphrasing the text without borrowing the language or structure used in an original source.

c) Checking the paraphrasing against the original text to avoid the accidental usage of some phrases or words in the text.

d) Keeping accurate notes when doing research.

e) Mastering procedure for citing sources.

f) Educating oneself on University plagiarism policies.

\section{Statement of the Problem}

It has been observed with dismay that many final year Education students find it difficult to write their projects without copying other people's works, hence many are unable to explain or defend their written projects. Even, some graduate students, are not better in research work. This is a disturbing situation in view of the fact that it is through research that knowledge is created and refined, discoveries and innovations are made and solutions proffered for problems in Education and other fields of study. Taking 
cognizance of this practice, the researcher embarked on the study.

\section{Purpose of the Study}

The study examined the management strategies of Imo State University in curbing the prevalence of students' plagiarism in project writing. Specifically, the study sets to:

1. ascertain the causes of students plagiarism in project writing.

2. determine the types of plagiarism students get involved in.

3. examine the strategies used by the University to curb plagiarism in students project writing.

4. find out ways of preventing cases of project plagiarism amongst University students.

\section{Research Questions}

The following research questions are posed to guide the study.

1. What are the causes of students' plagiarism in research project writing?

2. What type of plagiarism do students commonly engage in, in research project writing?

3. What strategies does the university use to curb students project plagiarism?

4. How could cases of students' project writing plagiarism be prevented?

\section{Hypotheses}

The following three hypotheses are formulated and tested at 0.05 level of significance.

1. There is no significant difference in the mean responses of Science and Arts Education students on the causes of students' project writing plagiarism.

2. There is no significant difference in the mean responses of Science and Arts Education students on the Universities strategies for curbing plagiarism in students' project writing.

3. There are no significant differences in the mean responses of Science and Arts students on how to prevent plagiarism in students' project writing.

\section{Methodology}

The design employed is a Case study using Education students, Imo State University to shed light on the phenomenon. The population for the study was 500 final year Education students of 2012/2013 Session who were writing their project. A sample size of 200 students drawn from all the disciplines in the Education Faculty mainly grouped into two categories of Arts Education and Science Education were used. A clustered proportionate random sampling technique was used to draw students from each of the categories of science and Arts Education students respectively,

A researcher made 36 item, 4 point rating scale tagged "Causes of Students Plagiarism and Management Strategies for Curbing Plagiarism (CSPMSCP) was used to collect data. The instrument has a response option of Strongly Agree (SA) Agree (A), Disagree (D), and Strongly Disagree (SD) and was validated by two experts in Educational Measurement and Evaluation and two from Educational Management. The reliability of the instrument was ensured through the use of Test-retest method, whereby 30 students outside the sample were administered with the instrument twice within two weeks interval. The two sets of responses got were correlated using Pearson Product moment correlation-coefficient (Pearson $\mathrm{r}$ ) which yielded high reliability index of 0.90 .

Thereafter, the instrument was personally administered with the assistance of four Course representatives after the end of the respondents' final year last paper examination. The data collected were collated and presented in frequency tables in clusters according to the Research Questions. The research questions were answered using a benchmark of 2.50 , and t-test statistics was used to test each of the hypotheses at 0.05 level of significance. 


\section{Results}

Research Question One: What are the causes of students' plagiarism in project writing?

Table 1. Mean Responses of Science and Arts Education Students on the Causes of Plagiarism

\begin{tabular}{|c|c|c|c|c|c|c|c|c|c|}
\hline \multirow[t]{2}{*}{$\mathrm{S} / \mathrm{N}$} & \multirow[t]{2}{*}{$\begin{array}{l}\text { Item statement: These factors make students to } \\
\text { plagiarize in project writing }\end{array}$} & \multicolumn{4}{|c|}{$\begin{array}{c}\text { GROUP A } \\
\text { Science Education Students }\end{array}$} & \multicolumn{4}{|c|}{$\begin{array}{c}\text { GRP GROUP B } \\
\text { Arts Education Students }\end{array}$} \\
\hline & & $\mathrm{X}$ & Ranks & SD & Remarks & $\mathrm{X}$ & Ranks & SD & Remarks \\
\hline $1 \mathrm{a}$. & Not properly taught on how to write project & 3.23 & $2^{\text {nd }}$ & 0.13 & Agreed & 3.18 & $2^{\text {nd }}$ & 0.08 & Agreed \\
\hline b. & Inadequate time to write the project & 3.32 & $1^{\text {st }}$ & 0.18 & Agreed & 2.90 & $10^{\text {th }}$ & 0.09 & Agreed \\
\hline c. & Laziness on the part of students & 3.11 & $4^{\text {th }}$ & 0.06 & Agreed & 3.14 & $3^{\text {rd }}$ & 0.05 & Agreed \\
\hline d. & Imitating others & 2.34 & $12^{\text {th }}$ & 0.39 & Disagreed & 2.92 & $9^{\text {th }}$ & 0.08 & Agreed \\
\hline e. & $\begin{array}{l}\text { Poor knowledge of how to get research } \\
\text { information and knowledge }\end{array}$ & 3.06 & $6^{\text {th }}$ & 0.03 & Agreed & 3.39 & $1^{\text {st }}$ & 0.19 & Agreed \\
\hline f. & Lack of confidence to write project & 3.17 & $3^{\text {rd }}$ & 0.92 & Agreed & 3.14 & $3^{\text {rd }}$ & 0.05 & Agreed \\
\hline g. & $\begin{array}{l}\text { Ignorance that copying the text of others as } \\
\text { ones own is an offence }\end{array}$ & 2.85 & $10^{\text {th }}$ & 0.09 & Agreed & 3.06 & $6^{\text {th }}$ & 0.01 & Agreed \\
\hline h. & Improper supervision by project supervisors & 2.01 & $9^{\text {th }}$ & 0.00 & Agreed & 2.88 & $12^{\text {th }}$ & 0.09 & Agreed \\
\hline I & $\begin{array}{l}\text { Not taught how to acknowledge sources of } \\
\text { information }\end{array}$ & 3.08 & $5^{\text {th }}$ & 0.04 & Agreed & 2.90 & $10^{\text {th }}$ & 0.09 & Agreed \\
\hline $\mathrm{J}$ & $\begin{array}{l}\text { Absence of university rules and policies } \\
\text { against plagiarism }\end{array}$ & 3.02 & $8^{\text {th }}$ & 0.01 & Agreed & 3.12 & $5^{\text {th }}$ & 0.07 & Agreed \\
\hline $\mathrm{K}$ & $\begin{array}{c}\text { Not knowing how to acknowledge sources of } \\
\text { text }\end{array}$ & 3.04 & $7^{\text {th }}$ & 0.02 & Agreed & 3.05 & $7^{\text {th }}$ & 0.00 & Agreed \\
\hline $\mathrm{L}$ & Expensiveness of project writing & 2.84 & $11^{\text {th }}$ & 0.01 & Agreed & 2.93 & $8^{\text {th }}$ & 0.07 & Agreed \\
\hline & Cluster mean & 3.01 & & 0.5416 & & 3.05 & & 0.0642 & \\
\hline
\end{tabular}

The data in table 1, show the responses of both science (Group A) and Arts Education(Group B) students on why students plagiarize in project writing. With the exception of item no.1d, imitating others, which only Group A agreed with, the respondents are in consensus agreement that the listed items $1 \mathrm{a}-1$ are the causes of plagiarism in students project writing. This is exemplified by the high Mean scores above 2.50 of the items which shows that both Science and Arts Education Students involve in plagiarism in project writing as a result of inadequate time for project, not properly taught on how to write project, lack of self-confidence, laziness, not taught how to acknowledge sources, poor knowledge of how to source research materials, ignorance of how to acknowledge sources of texts, absence of university's rule on plagiarism, improper project supervision, ignorance of the offence of plagiarism and expensiveness of project writing.

Though there are variations in the ranking of these items by the two groups of respondents, but the low Standard Deviation (SD) in all the items indicate close agreement of the respondents on the items as the causes of students plagiarism in project writing.

\section{Research Question Two: What types of Plagiarism do students commonly engage in, in writing project?}

Table 2. Mean Responses of Science and Arts Education Students on Types of Plagiarism

\begin{tabular}{|c|c|c|c|c|c|c|c|c|c|}
\hline \multirow[t]{2}{*}{$\mathrm{S} / \mathrm{N}$} & \multirow[t]{2}{*}{$\begin{array}{c}\text { Item statement: Students engage in this } \\
\text { type of plagiarism in their project } \\
\text { writing }\end{array}$} & \multicolumn{4}{|c|}{$\begin{array}{c}\text { GROUP A } \\
\text { Science Education Students }\end{array}$} & \multicolumn{4}{|c|}{$\begin{array}{c}\text { GRPA GROUP B } \\
\text { Arts Education Students }\end{array}$} \\
\hline & & $\mathrm{X}$ & Ranks & SD & Remarks & $X$ & Ranks & SD & Remarks \\
\hline $2 a$ & $\begin{array}{l}\text { Obtaining and submitting projects } \\
\text { written by someone else }\end{array}$ & 3.19 & $1^{\text {st }}$ & 0.16 & Agreed & 3.32 & $2^{\text {nd }}$ & 0.04 & Agreed \\
\hline b. & $\begin{array}{l}\text { Copying text from books/journals } \\
\text { without citing the source }\end{array}$ & 2.26 & $7^{\text {th }}$ & 0.38 & Disagreed & 3.17 & $5^{\text {th }}$ & 0.04 & Agreed \\
\hline c. & $\begin{array}{l}\text { Copying from web pages and pasting } \\
\text { without references }\end{array}$ & 2.93 & $3^{\text {rd }}$ & 0.01 & Agreed & 3.29 & $3^{\text {rd }}$ & 0.04 & Agreed \\
\hline d. & $\begin{array}{l}\text { Paraphrasing original ideas of others and } \\
\text { claiming them as theirs }\end{array}$ & 2.91 & $4^{\text {th }}$ & 0.00 & Agreed & 3.37 & $1^{\text {st }}$ & 0.08 & Agreed \\
\hline e. & $\begin{array}{l}\text { Attributing the citation of a text to a false } \\
\text { authorship }\end{array}$ & 2.81 & $6^{\text {th }}$ & 0.06 & Agreed & 3.12 & $6^{\text {th }}$ & 0.06 & Agreed \\
\hline f. & $\begin{array}{l}\text { Changing the numbers of respondents } \\
\text { and responses in research data }\end{array}$ & 3.10 & $2^{\text {nd }}$ & 0.11 & Agreed & 3.11 & $7^{\text {th }}$ & 0.07 & Agreed \\
\hline g. & $\begin{array}{l}\text { Reusing once previous published } \\
\text { materials }\end{array}$ & 2.82 & $5^{\text {th }}$ & 0.05 & Agreed & 3.21 & $4^{\text {th }}$ & 0.01 & Agreed \\
\hline & Cluster Mean & 2.86 & & 0.1100 & & 3.23 & & 0.0486 & \\
\hline
\end{tabular}


The types of plagiarism students commonly engage in while writing projects are clearly exposed and ranked in table 2 . The high Mean scores above 2.50 recorded and ranked in all the items except item no. $2 \mathrm{~b}$ for the science students, established that the types of plagiarism students engage in are, submitting project written by someone else (GRP A $=\mathrm{X}=3.9$, Ranking $=1^{\text {st }}$ and GRP $B=X=3.32$, Ranking $\left.2^{\text {nd }}\right)$, web copy and paste $\left(A=X=2.93\right.$, Ranking $=3^{\text {rd }}$ and $B=X=3.29$, Ranking $\left.=3^{\text {rd }}\right)$, paraphrasing and claiming someone's ideas $\left(A=X=2.91\right.$, Ranking $4^{\text {th }}$ and $B=X=3.37$, Ranking $\left.1^{\text {st }}\right)$ reusing previously published materials (GRP A $=X=2.82$, Ranking $5^{\text {th }}$ and GRP B $=X=3.2$, Ranking $4^{\text {th }}$ ). Other types of plagiarism students engage in are, changing the number of respondents and responses in research data (GRP $A=X=3.10$, Ranking $2^{\text {nd }}$ and GRP $\mathrm{B} X=3.11$, Ranking $7^{\text {th }}$ ) attributing citation to a false authorship (GRP A X $=2.81$, Ranking $6^{\text {th }}$ and GRP $B=X=3.12$, Ranking $\left.6^{\text {th }}\right)$ and copying text without citing the sources which GRP A disagreed with a mean score of 2.27 and ranked $7^{\text {th }}$ while GRP B consented to it with a mean score of 3.17 and ranked $5^{\text {th }}$.

Research Question Three: What strategies does the university use to curb plagiarism in project writing?

Table 3. Mean Responses of Science and Arts Education on Strategies used by Imo State University

\begin{tabular}{|c|c|c|c|c|c|c|c|c|c|}
\hline \multirow[t]{2}{*}{$\mathrm{S} / \mathrm{N}$} & \multirow{2}{*}{$\begin{array}{l}\text { Item statement: The following } \\
\text { strategies are used by your University } \\
\text { to reduce plagiarism in students } \\
\text { project writing }\end{array}$} & \multicolumn{4}{|c|}{$\begin{array}{c}\text { GROUP A } \\
\text { Science Education Students }\end{array}$} & \multicolumn{4}{|c|}{$\begin{array}{c}\text { GRPA GROUP B } \\
\text { Arts Education Students }\end{array}$} \\
\hline & & $\mathrm{X}$ & Ranks & SD & Remarks & $\mathrm{X}$ & Ranks & SD & Remarks \\
\hline $3 a$. & Teaches research method course & 3.24 & $1^{\text {st }}$ & 0.30 & Agreed & 3.32 & $1^{\mathrm{st}}$ & 0.19 & Agreed \\
\hline b. & $\begin{array}{l}\text { Made policies and rules against } \\
\text { students copying in project writing }\end{array}$ & 3.00 & $2^{\text {nd }}$ & 0.16 & Agreed & 2.98 & $4^{\text {th }}$ & 0.01 & Agreed \\
\hline c. & Rejects any copied project & 2.90 & $3^{\text {rd }}$ & 0.10 & Agreed & 3.00 & $3^{\text {rd }}$ & 0.01 & Agreed \\
\hline d. & Gives a low grade to the project & 2.49 & $5^{\text {th }}$ & 0.13 & Disagreed & 2.90 & $5^{\text {th }}$ & 0.05 & Agreed \\
\hline e. & $\begin{array}{l}\text { Expels students who plagiarizes in } \\
\text { project writing }\end{array}$ & 2.17 & $7^{\text {th }}$ & 0.32 & Disagreed & 2.64 & $7^{\text {th }}$ & 0.20 & Agreed \\
\hline f. & Fails students & 2.34 & $6^{\text {th }}$ & 0.22 & Disagreed & 2.90 & $5^{\text {th }}$ & 0.05 & Agreed \\
\hline g. & $\begin{array}{c}\text { Teaches students referencing and } \\
\text { citing skills }\end{array}$ & 2.90 & $3^{\text {rd }}$ & 0.10 & Agreed & 3.17 & $2^{\text {nd }}$ & 0.10 & Agreed \\
\hline & Cluster mean & 2.72 & & 0.1900 & & 2.99 & & 0.0871 & \\
\hline
\end{tabular}

The data in Table 3 show the various strategies the university management adopts for curbing plagiarism in students project writing. These are teaching students research method, which has mean scores of 3.24 and 3.32 and ranked first by both groups of respondents, provision of policies against copying in project writing (X 3.00 and X 2.98, and ranked $2^{\text {nd }}$ and $4^{\text {th }}$ by the two groups respectively, rejection of any copied project and teaching students referencing and citing skills which have mean scores above 2.50 and ranked $3^{\text {rd }}$ by the two groups, and $3^{\text {rd }}$ and $2^{\text {nd }}$ respectively by the two groups for item no $3 \mathrm{~g}$.

However, there is a disagreement between the Science Education Students and Arts Education Students on Item Nos. 3d, e and $f$ as strategies university adopts in curbing plagiarism. This is exemplified by the mean scores below 2.50 recorded by the science students on the strategies of giving a low grade to a copied project, expelling students who plagiarized and failing students who plagiarized.

\section{Research Question Four: How could cases of students' project writing plagiarism be stopped?}

Table 4. Mean Responses of Science and Arts Students on How to Prevent Plagiarism

\begin{tabular}{|c|c|c|c|c|c|c|c|c|c|}
\hline \multirow{3}{*}{$\mathrm{S} / \mathrm{N}$} & \multirow{3}{*}{$\begin{array}{l}\text { Item statement: Strategies for preventing } \\
\text { students project writing plagiarism are }\end{array}$} & \multicolumn{4}{|c|}{ GROUP A } & \multicolumn{4}{|c|}{ GRPA GROUP B } \\
\hline & & \multicolumn{4}{|c|}{ Science Education Students } & \multicolumn{4}{|c|}{ Arts Education Students } \\
\hline & & $\mathrm{X}$ & Ranks & SD & Remarks & $\mathrm{X}$ & Ranks & SD & Remarks \\
\hline 4a. & $\begin{array}{l}\text { Teaching plagiarism and its implication } \\
\text { to students }\end{array}$ & 3.62 & $2^{\text {nd }}$ & 0.23 & Agreed & 3.37 & $1^{\mathrm{st}}$ & 0.18 & Agreed \\
\hline b. & $\begin{array}{l}\text { Adequate and proper teaching of how to } \\
\text { carry out research }\end{array}$ & 3.65 & $1^{\text {st }}$ & 0.24 & Agreed & 3.33 & $2^{\text {nd }}$ & 0.16 & Agreed \\
\hline c. & Proper project supervision by lecturers. & 3.36 & $5^{\text {th }}$ & 0.08 & Agreed & 3.26 & $3^{\text {rd }}$ & 0.12 & Agreed \\
\hline d. & Early approval of research topic & 3.38 & $3^{\text {rd }}$ & 0.09 & Agreed & 3.13 & $5^{\text {th }}$ & 0.04 & Agreed \\
\hline e. & $\begin{array}{l}\text { Failing students who plagiarized in their } \\
\text { project work }\end{array}$ & 2.86 & $9^{\text {th }}$ & 0.21 & Agreed & 2.74 & $10^{\text {th }}$ & 0.18 & Agreed \\
\hline f. & $\begin{array}{c}\text { Giving lower grades to plagiarized } \\
\text { projects }\end{array}$ & 2.75 & $10^{\text {th }}$ & 0.28 & Agreed & 2.89 & $7^{\text {th }}$ & 0.09 & Agreed \\
\hline g. & Rejecting plagiarized projects & 3.10 & $6^{\text {th }}$ & 0.08 & Agreed & 2.78 & $9^{\text {th }}$ & 0.16 & Agreed \\
\hline $\mathrm{h}$. & $\begin{array}{l}\text { Putting in place policies against } \\
\text { plagiarism }\end{array}$ & 3.09 & $7^{\text {th }}$ & 0.08 & Agreed & 2.86 & $8^{\text {th }}$ & 0.16 & Agreed \\
\hline I & $\begin{array}{l}\text { Publishing names of culprits of } \\
\text { plagiarism }\end{array}$ & 3.08 & $8^{\text {th }}$ & 0.09 & Agreed & 2.96 & $6^{\text {th }}$ & 0.06 & Agreed \\
\hline $\mathrm{J}$ & $\begin{array}{l}\text { Mounting in-house workshop for project } \\
\text { students }\end{array}$ & 3.38 & $3^{\text {rd }}$ & 0.09 & Agreed & 3.26 & $3^{\text {rd }}$ & 0.12 & Agreed \\
\hline & Cluster mean & 3.23 & & 0.1570 & & 3.06 & & 0.1180 & \\
\hline
\end{tabular}


The data in table 4 show the Mean scores (X) and rankings of strategies for preventing cases of students plagiarizing in project writing. Both students of Science Education and Arts Education are in agreement with all the listed items as strategies for the prevention of plagiarism in project writing. The recorded item's Mean scores above 2.50 and the cluster mean scores of 3.23 for the Science Education and 3.06 for the Arts Education Students which are greater than the criterion mean of 2.50 established that all the items nos. $4 \mathrm{a}-\mathrm{j}$ are ways of preventing students plagiarism in project writing.

This posits that strategies for reducing students project writing plagiarism in Imo state university are: teaching students the implications of plagiarism, adequate and proper teaching of research method, proper project supervision by the lecturers, early approval of research topic, failing students who plagiarize, giving lower grades to plagiarized project, rejection of plagiarized project, putting in place plagiarism policies, publishing names of students who plagiarized and mounting in-house workshop for project students on accurate note keeping, citing and paraphrasing procedures in research.

\section{Test of Hypotheses}

$\mathrm{Ho}_{1}$ : There is no significant difference in the mean responses of Science and Arts Education students on the causes of students' project plagiarism.

Table 5. t-test of difference between the mean scores of Science and Arts Education students on the causes of project plagiarism.

\begin{tabular}{|c|c|c|c|c|c|c|c|c|c|}
\hline Group & $\begin{array}{l}\text { No of } \\
\text { items }\end{array}$ & $\begin{array}{l}\text { Mean of } \\
\text { Means }\end{array}$ & Std Dev. & $\begin{array}{l}\text { Sample } \\
\text { Size }\end{array}$ & $\mathrm{Df}$ & $\mathrm{t}$-cal & t-tab & $\begin{array}{l}\text { Level of } \\
\text { significance }\end{array}$ & Decision \\
\hline $\begin{array}{l}\text { Science Education } \\
\text { Students }\end{array}$ & 12 & 3.01 & 0.5416 & 100 & \multirow{2}{*}{22} & \multirow{2}{*}{0.74} & \multirow{2}{*}{2.974} & \multirow{2}{*}{0.05} & \multirow{2}{*}{$\begin{array}{l}\text { Accept } \\
\mathrm{Ho}_{1}\end{array}$} \\
\hline $\begin{array}{l}\text { Arts Education } \\
\text { Students }\end{array}$ & 12 & 3.05 & 0.0642 & 100 & & & & & \\
\hline
\end{tabular}

The results in table 5 indicate a t-cal of 0.74 which is less than the $t$-tab of 2.074 at 22 degree of freedom and at 0.05 level of significance. The null hypothesis is therefore accepted. This means that there is no statistically significant difference between the mean scores of Science and Arts education students on the causes of project plagiarism.

$\mathrm{Ho}_{2}$ : There is no significant difference in the Mean responses of Science and Arts Education Students on the University's strategies for curbing students' project plagiarism.

Table 6. t-test of difference of Science and Arts Education students' Mean scores on the University strategies for curbing project plagiarism.

\begin{tabular}{|c|c|c|c|c|c|c|c|c|c|}
\hline Group & $\begin{array}{l}\text { No of } \\
\text { items }\end{array}$ & $\begin{array}{c}\text { Mean of } \\
\text { means }\end{array}$ & Std Dev. & $\begin{array}{l}\text { Sample } \\
\text { size }\end{array}$ & Df & t-cal & $\mathrm{t}$-tab & $\begin{array}{c}\text { Level of } \\
\text { significance }\end{array}$ & Decision \\
\hline $\begin{array}{l}\text { Science Education } \\
\text { Students }\end{array}$ & 7 & 2.72 & 0.1900 & & \multirow{2}{*}{12} & \multirow{2}{*}{1.993} & \multirow{2}{*}{2.179} & \multirow{2}{*}{0.05} & \multirow{2}{*}{$\begin{array}{l}\text { Accept } \\
\mathrm{Ho}_{2}\end{array}$} \\
\hline $\begin{array}{l}\text { Arts Education } \\
\text { Students }\end{array}$ & 7 & 2.99 & 0.0871 & 100 & & & & & \\
\hline
\end{tabular}

The result in table 6 shows no significant difference between the mean responses of Science and Arts Education Students on the strategies used by the university in curbing students' research project plagiarism. This is evidenced by the t-cal of 1.993 which is less than the t-tab of 2.179 at 0.05 level of significance. Hence, the null hypothesis of no significant difference is accepted.

$\mathrm{Ho}_{3}$ : there is no significant difference in the Mean responses of Science and Arts Education students on how to prevent plagiarism in students' project writing.

Table 7. $\mathrm{t}$ - test of difference of mean responses of Science and Arts Education students on the prevent ion of project plagiarism.

\begin{tabular}{|c|c|c|c|c|c|c|c|c|c|}
\hline Group & $\begin{array}{c}\text { No of } \\
\text { items }\end{array}$ & $\begin{array}{c}\text { Mean of } \\
\text { means }\end{array}$ & $\begin{array}{c}\text { Std } \\
\text { Dev. }\end{array}$ & $\begin{array}{c}\text { Sample } \\
\text { size }\end{array}$ & Df & t-cal & t-tab & $\begin{array}{c}\text { Level of } \\
\text { significance }\end{array}$ & Decision \\
\hline $\begin{array}{c}\text { Science Education } \\
\text { Students }\end{array}$ & 10 & 3.23 & 0.1570 & 100 & 18 & 2.615 & 2.101 & 0.05 & ${\mathrm{Reject} \mathrm{Ho}_{3}}$ \\
\hline $\begin{array}{c}\text { Arts Education } \\
\text { Students }\end{array}$ & 10 & 3.06 & 0.1180 & 100 & 18 & \\
\hline
\end{tabular}

The result in table 7 tested at 0.05 level of confidence shows t-cal to be 2.615 , which is greater than the t-tab of 1.66. It then means that the null hypothesis which says there is no significant difference in the mean responses of Science and Arts Education students on ways of preventing students project plagiarism is rejected.

\section{Discussion of Findings}

The study revealed that students' research project plagiarism in Imo State University is caused by the following factors, inadequate time for project, inadequate teaching of research method, lack of self-confidence, 
laziness, ignorance of how to source for materials, acknowledge sources and plagiarism implications, improper project supervision, absence of University rules on plagiarism, and expansiveness of project writing. These causes are unanimously accepted by both science and arts Education students as no significant difference in their mean responses was found.

The findings are in line with the views of Bal, $(2007)^{[6]}$, Nwana (2008) $)^{[5]}$ and Awujo (2013) ${ }^{[7]}$, who noted students laziness, ignorance of plagiarism, inadequate time, expensiveness of project writing, poor teaching of research method and improper project supervision to be contributory factors to project plagiarism.

On the issue of the types of plagiarism students commonly engage in, the findings included; submission of project written by someone else, web copy and paste, paraphrasing and claiming ownership of someone's ideas, revising previously published materials and changing the number of respondents and their responses in a research data as prevalent among students. Other found plagiarism type students engage in include attributing citation to a false authorship and copying text without citing the sources. These findings totally authenticate the outlined variables by Bal $(2007)^{[6]}$ as the types of plagiarism that students commonly practice in the Universities.

The strategies adopted by the University to curb students' research project plagiarism were found to be, teaching students Research method, provision of rules and regulations against copying project, rejection of copied projects and teaching students referencing and citing skills. The hypothesis proved no dissenting views in the opinions of Science and Arts Education students on the University strategies in curbing project plagiarism.

There is no gain-saying the fact that teaching Research method course in the University is one of the ways of inculcating research skills to students to prevent any case of plagiarism. Nwana $(1985)^{[4]}$ stressed this point when he posits that lecturers teach students how to carry out and write research because research report is a prerequisite for awarding any degree. The issues that worry the researcher on these findings are, do the students take this research method course seriously? Do the lecturers teach the course very well as noted by Awujo (2013) $)^{[7]}$ ? How does the University dictate a copied project as to reject it? And if there are rules or policies against project plagiarism, are they enforced, or on paper?. These and more call for further study because if they are actually the strategies the University takes, they seem to be not very effective, so more proactive and practical measures need to be adopted urgently to save a situation.

Furthermore, the study x-rayed ways of preventing project plagiarism to be creating students awareness on the implications of plagiarism, adequate and proper teaching of the research method course, proper project supervision by the lecturers, early approval of research topic, failing culprits of plagiarism and giving lower grades to a plagiarized project. Other preventive measures by the findings are rejection of plagiarized projects, putting in place plagiarism policy in the University, publishing names of culprits of plagiarism and mounting in-house research project writing workshop for project students. The mean responses of Science and Arts Education students differ in these preventive measures to project plagiarism. This calls for attention to the tips for the avoidance of students plagiarism outlined by the Indiana University $(2004)^{[8]}$, as ways of preventing plagiarism in the University.

\section{Conclusion and Recommendations}

Research generally and Education research in particular holds the key to the development of education in any country, and students who are potential future scholars seriously have to acquire research skills for continuity of scholarship. It then implies that the University management and other Education stakeholders have a very big challenge to curb the prevalent cases of students' research project plagiarism. This is expedient, to protect the image of the University and even the project supervisors when such projects are uploaded in the internet.

In view of these findings, it is recommended that:

1. students should be made to know the 'implications of plagiarism

2. the university should run a plagiarism test using the university data analysis ,and research centre which aims at improving on the value of research analysis and information technology expertise in academics.

3. students should be exposed to project workshops from time to time to instill positive research culture in them.

4. only genuine and good projects should be uploaded in the internet which could attract foreign incentives

5. the university should motivate a student with the best genuine project so as to entice other students and

6. lecturers should carryout proper and adequate teaching and supervising of students for project writing.

\section{REFERENCES}

[1] Federal Republic of Nigeria. National Policy on Education. Abuja: NERDC;2004.

[2] Nwokeocha, S. Research Methods in Education for a Global Audience. South Africa: African Forum of Teaching Regulatory Authorities; 2004.

[3] Nwankwoala, H.N.L \& Nwaneri P.N. Inadequate Utilization of Educational Research Reports and Tertiary Education in Nigeria: Issues on Contemporary Nigerian Education, Owerri: Corporate Impressions; 2010.

[4] Nwana, O.C. Introduction to Education Research, Ibadan: 
Heinemann Educational Books Ltd; 1985.

[5] Nwana, O.C. University Academics in Nigeria, Memoirs of an Insider, Owerri: Peace Wise, 178 - 179;2008.

[6] U.S Public Health Services (1989), Responsibility of PHS awardee and applicant institutions for dealing with and reporting possible misconduct in science. 54 Federal Register 151; 42 CRF Part 50, 32446-51.

[7] Newstead, S.E, Franklyn-Strokes, A \& Armead, P (1999), Individual differences in students cheating. Journal of Educational Psychology, 88(2), 229-241
[8] Bal, K.S. Plagiarism Among University Students: Intentional or Accidental, Journal of NELTA, Vol. 12 (1-2); 2007.

[9] Awujo C.G. Research Anxiety Among Education Undergraduates. African Journal of Higher Education Studies and Development (AJHESD). Issue 3; 2013.

[10] Indiana University, Bloomington Writing Tutorial Services Centre for Innovative Teaching and Learning (2004). http://sja/ucdavisedu/.void.htm.[Accessed $20^{\text {th }}$ October, 2014]. 